\title{
Knowledge transfer between universities and smes and regional development. The role of the clusters as communities of practice
}

\author{
Costin LIANU \\ USH Pro Business, Bucharest, Romania \\ clianu@gmail.com \\ Irina Gabriela RĂDULESCU \\ Petroleum-Gas University of Ploiești, Romania \\ iri_radulescu@yahoo.com \\ Corina Simona DOBRE (GUDEI) \\ Bucharest University of Economic Studies, Bucharest, Romania \\ corinagudei@yahoo.com \\ Cosmin LIANU \\ Bucharest University of Economic Studies, Bucharest, Romania \\ cosminlia@hotmail.com
}

\begin{abstract}
The Exchange of knowledge between universities and SMEs became a source of sustainable competitive advantages. The innovation capacity of SMEs is under pressure for various reasons since knowledge management is more costly and innovation readiness more difficult to be achieved. Higher Education Institutions (HEIs) became in this context critical players in the knowledge-based economy to interact with small companies. The traditional functions of universities are the generation of knowledge (research) and its transmission (teaching) are reconsidered in order to better serve the managers.

This paper investigate conditions SMEs and universities may better work together, assuming that a pro university-SMEs cooperation behaviour at the level of the SMEs managers and universities is an essential factor of an efficient transfer of knowledge. Evidence of this interaction from development regions of Romania are shown in order to identify emerging cooperation patterns. Another area this paper investigates is the interaction of universities and SMEs when they are bound together in a longer cooperation alliances, in clusters. Actions to develop clusters include universities as central resource. The research intends to review the role of the university in cluster development for Romanian development regions on their struggle to occupy a role in European smart specialization processes. As a main conclusion, the article argues that smart specialization and communities of practice are interconnected concepts enabling innovation processes in university-industry interaction. Knowledge transfer may be more efficient when clusters and universities are interacting on a long-term basis.
\end{abstract}

Keywords: entrepreneurial universities, innovation, smart specialization, SMEs, clusters.

\section{Introduction}

In a knowledge-based economy with accelerated transformation processes the source of sustainable competitive advantages is more difficult to be managed by SMEs especially, due to costly adoption of technological innovation, of digital transformation or other crucial innovation challenges. Managers may find themselves in critical situation of not coping the pace with the competition of other SMEs or business alliances, platforms or large organizations.

There are certain limits of SMEs and start-ups to reach an innovation readiness level able to bring to the market innovative product or services and adapt to new business models.

DOI: 10.2478/picbe-2020-0046, pp. 490-504, ISSN 2558-9652| Proceedings of the 14th International Conference on Business

Excellence 2020 
Looking for ways to compete and innovate, managers discover different ways to cooperate: like among themselves in alliances like clusters, consortia or hubs; with larger companies; with universities and research institutes; with business accelerators.

In this context, universities are more and more in the position to interact with SMEs managers but this is not coming only because companies may need them. Universities also need to adapt their traditional functions and capacities moving from a more passive transfer of knowledge to more pro-active actions to attract the managers in a long term cooperation where developing trust is essential. One important way to develop trust is through communities of practice, where managers are teaming with students, researchers and professors in order to innovate.

Another aspect which may favour but also may create constraints in the interaction between companies and universities is the increased processes of specialization among producers. Indeed, looking in the global value chains, we may notice deepening of specializations since the complexity of the goods is increasing. SMEs may find themselves in second, third or fourth layer of suppliers for a finished good. Even more, they have to cooperate more with horizontal suppliers to be on the market or to work on platforms to promote their goods. In these new situations, universities may deal with groups of managers organized in business alliances like clusters. This may add complexity to interaction but also can bring more trust.

When managers are bound together in a longer cooperation in clusters, universities may find more difficult to cooperate, since they may feel overwhelmed. Acting pro-active in this respect is a crucial change of mentality. Universities should assume a new role, not only to meet the needs of this group of companies but also to create, facilitate and develop clusters where universities play an important role as promoters of communities of practices towards smart specialization.

Clusters, as structures facilitating innovation at national, regional or international levels are the result of cooperation between different stakeholders like central or local public administration authorities, research and development units, universities, chambers of commerce and industry, employers' associations, professionals, financial institutions. Acting together, these entities can provide an ecosystem capable of covering all their competitive aspirations: competitiveness strategies, product development, planning, research-development, financing, capitalizing on the results of the research at internal and international level, specialized services.

One important purpose of these structures is to capitalize on the results of technological research and development, through innovative activities with the role of increasing the quality and competitiveness of products, processes and services, creating new jobs and sustainable development of the economy.

Because innovation cannot thrive in isolation, cluster-like structures represent regional ecosystems of industries, which present a diverse range of innovation-generating interdependencies. Offering a conducive environment in which entrepreneurs and other entities can work together to identify common solutions to current challenges, clusters stimulate competitiveness and innovation.

There are several definitions of the cluster concept. Prof. Michael Porter defines the cluster as "a geographical concentration (region, country) of interconnected companies (especially SMEs), specialized suppliers, service providers, companies from related industries, universities, research institutes and trade associations, public administrations local from specific fields, which compete but also cooperate". Cluster or cluster networks impose certain conditions 
in order to become innovative and give results. These conditions are: the existence of a critical mass (complementary activities and companies; interconnection through a common interest; existing competences complementary and demonstrated); trust between entities; voluntary participation; development of a common strategy; dynamic and open cooperation (partnership agreement); professional and assured management through well-defined structures; benefits for all members (stimulating technology transfer; attracting foreign investments; defending intellectual property rights; training etc.); common market; SME internationalization, etc.

Clusters are considered to be an optimum place for smart specialization and communities of practice since they represent economic regional concentrations. Even more, they are defined as structures involving universities. One major assumption is innovation processes and knowledge transfer may be more efficient when clusters and universities are interacting on a long-term basis.

\section{Literature review}

Innovation is the most important element of competitiveness, growth and long-term employment. Collaboration between the economic environment, the academic environment and the state is essential for improving the innovation ecosystem (Etzkowitz et al., 2000). According to Klofsten and Jones-Evans (2000), universities are catalytic entities that can improve employment opportunities in local industry, especially in high-tech and knowledge-based sectors as a crucial source of direct and indirect employment opportunities.

The Universities can become involved in national innovation systems through three important missions. Their first role is to educate and provide society with excellent human resources, which are essential for economic growth. Second, it conducts basic research that can be applied and developed in different technological categories, thus influencing long-term economic growth. The third role is to act as a source of knowledge for companies experiencing problems in research and development (Fukugawa, 2013). The three missions of a university greatly influence regional innovation and economic growth and lead to the current model of the entrepreneurial university (Philpott et al., 2011).

Therefore, the Triple Helix model confirms that the university can play an important role in innovation in knowledge-based societies (Etzkowitz and Leydesdorff, 2000).

Recently, empirical studies have addressed the third role of universities in promoting economic growth by showing significant knowledge spillovers from university researches received by small technology-based enterprises. These results could be measured by the number of innovations or the development of new products (Acs et al., 1994; Rothaermel and Deeds, 2004), novel innovations (Romijn and Albaladejo, 2002), the research and development rate of return (Link and Rees, 1990), the number of patents (Audretsch and Vivarelli, 1996) and sales (Baum et al., 2000).

Clusters are now the subject of a whole series of documents issued by national and international organizations (OECD, 2010; European Commission, 2008) and based on numerous experience the authorities promote the idea that due to the clusters the competitiveness increases, the labor force specializes, regional companies and economies are developing.

The definition given by Michael Porter in the 1980s is the most widespread, but not unanimously accepted. Porter describes a "diamond of competitive advantage" which should be the basis of any cluster. The main elements of diamond are made up of factors of production, demand, the interdependent and support sectors, the strategy, structure and competitors of the company (Porter, 1998). Other authors consider spin-out business networking or business 
focused on projects (Asheim et al., 2006) or take into account the proximity component (Malmberg and Power, 2006).

The role of universities in regional development is reinforced by smart specialization strategies aimed at identifying a set of priorities for investments (Kemptons et al., 2013). These can be pursued through stakeholder links by involving the government, academia, industry and society along the quadruple helix (Committee of the Regions, 2014) in the so-called entrepreneurial discovery process (Secondo et. al, 2017).

A community of practice $(\mathrm{CoP})$ is a group of people who share a common activity of knowledge management through a collective learning process. The concept was conceived by cognitive anthropologist Jean Lave and educational theorist Etienne Wenger in their 1991 book Situated Learning (Lave and Wenger, 1991). Wenger then significantly expanded on the concept in his 1998 book Communities of Practice (Wenger, 1998).

However, Communities of practice are not new area of knowledge and research: this type of learning has existed for as long as people have been learning and sharing their experiences through storytelling. The idea is rooted in American pragmatism, especially C. S. Peirce's concept of the "community of inquiry" (Shields, 2003), but also John Dewey's principle of learning through occupation (Wallace, 2007).

A CoP can evolve naturally because of the members' common interest in a particular domain or area, or it can be created deliberately with the goal of gaining knowledge related to a specific field. It is through the process of sharing information and experiences with the group that members learn from each other and have an opportunity to develop personally and professionally (Lave and Wenger, 1991).

CoPs can exist in physical settings, for example, a lunch room at work, a field setting, a factory floor, or elsewhere in the environment, but members of CoPs do not have to be colocated. They form a "virtual community of practice" (VCoP) (Dubé et al., 2005) when they collaborate online, such as within discussion boards and newsgroups, or a "mobile community of practice" (MCoP) (Kietzmann et al., 2013) when members communicate with one another via mobile phones and participate in community work on the go.

Smart specialization can be understood both as a policy instrument as well as managerial process of innovation. As a policy instrument, smart specialization was defined by Cohesion Policy of the European Commission. It is defined as way to identify strategic areas for intervention within a region "based both on the analysis of the strengths and potential of the economy and on an Entrepreneurial Discovery Process (EDP) with wide stakeholder involvement". It is based by as a "broad view of innovation including but certainly not limited to technology-driven approaches, supported by effective monitoring mechanisms" (European Commission, 2018). In the vision of the EU Commission smart specialization is not a planning doctrine or method and is targeting market opportunities. In the same time is related to economic concentrations and has exploratory meaning as an entrepreneurial discovery.

As OECD reports observe smart specialization policy is different from traditional industrial and innovation policies mainly defining innovation policy as an "entrepreneurial discovery", an aspect which is also the essence of the initial understanding of the concept, as a managerial process as it has been defined by its father Dominique Foray, as an interactive process in which market forces and the private sector are discovering and producing information about new activities and the government assesses the outcomes and empowers those actors most capable of realizing the potential (Foray, 2015). The concept is in this way a more bottom-up 
approach than traditional industrial policies where policy makers were more inclined to neglect the entrepreneurial visions in their public policy tools.

Smart specialization is considered however a confusing concept and structurally weak regions might be less likely to benefit from smart specialization (Hassink and Gong, 2019).

The link between communities of practice and smart specialization has been analyzed in previous research (Lianu, 2015) since most of the performing companies, clusters, networks engaged in smart specialization processes are, to a great extend CoPs. Only this collective approach, for the business model and for a regional value chain.

\section{Methodology}

In this paper we analyse the dimensions of interactions between universities with both individual SMEs and clusters and the conditions of an efficient interactions between them to favour smart specialisation. We also use a study case of a university entrepreneurial center specialized in cluster formation and development.

The following additional research tools were used: the online questionnaire as the main data collection tool, which was processed using the specific applications in Word and Excel; the focus group method conducted in three different fields. The questionnaire is one of the most effective tools in setting up a representative, accurate and complete database that facilitates the testing and verification of research hypotheses. We used two different questionnaires, one of them being dedicated to the persons working in SMEs, and the other dedicated to the teachers. The questionnaire comprised 11 questions and was filled in by 21 managers from the companies included in the target group and 20 teachers from higher education institutions. Data correlation and systematization was performed in an Excel file, in order to prepare them for statistical processing. For a more accurate and consistent analysis, the collected data was grouped according to certain research variables: activity field; different forms of cooperation between universities and SMEs; necessary qualities of external partners which can deliver knowledge transfer.

In order to understand the way of managers of SMEs can adopt collaborative approach among themselves in business alliances like clusters we also used the focus group methodology related to discussions organized with 80 companies acting in organic food sector divided in beekeeping and fruits and vegetables, cereals and medical herbs.

\section{Results and discussions}

\section{Focus group on cluster cooperation and transfer of knowledge}

To identify the needs of the SMEs in some clusters in Romania and the way the universities may address these needs we have used the focus group method in three events which took place in Export Business Centers from Bacău and Ploiesti and at Chamber of Commerce, Industry, and Agriculture from Teleorman. The results of applying the focus group method were processed from 4 thematic focus groups. Most of the companies from the focus group was in favour of cluster approach, involving universities, due to various reasons and arguments summarized below:

Focus group - Organic beekeeping: building a collective brand, indicating the potential clients, the Romanian origin of the ecological honey and of the specific properties, by regions in order to be attractive on distribution channels; inscription on the label of bee products: "Produced in Romania" for larger group of producers; the use of honey not only as a functional food, but also 
as a treatment for maintaining health, honey products being recognized for therapeutic effects, Romania being the first place in the world in the field of Apitherapy; honey producers have no practical knowledge and skills to carry out export activities; honey and honey products are marketed in bulk, in large containers, the processing component not being developed on the value chain of honey; there is no regional apiculture brand; the producers lack trust to organized in associations, clusters or cooperatives; even constituted cooperatives or other alliances do not work and fail to fulfil the objectives for which they were set up, most often due to the faulty management; the poor remuneration of the managers of cluster structures; early knowledge (one year before signing contracts with potential customers) of the requirements of companies collecting honey and organic honey products is a priority among the needs of SMEs in the sector (this information concerning the quantities requested, the purchase price as well as the delivery conditions, are important for the producers, the necessary estimation of the necessary material and financial resources necessary for the production activity); excessive bureaucracy represents a constraint on the development of the activity of the associative structures.

Focus group - Organic fruits and vegetables: setting up of a collaborative online platform, dedicated to innovation and export activities, to facilitate access to large retailers, this being necessary since the subsector of organic vegetables is not yet developed at national level; setting up of centers for collecting and processing raw materials to add value to the obtained products, their individual processing requiring high expenses and investments, which companies can't realize, individually; lack of knowledge about the markets; potential exporters need to be informed and trained, in order to be able to initiate and develop export activities; access to finance.

Focus group - Medicinal herbs: in the local market, the demand for organic herbs is relatively low and they need knowledge how to export; the manufacturers identify a small number of customers for purchasing organic herbs. In these conditions, they are forced to concentrate all their efforts for the loyalty of these customers, not having the possibility to negotiate a fair price on the product.

In conclusion, analysing these SMEs needs in the focus groups, one may notice that in the early stage of cooperation in clusters, where most of Romanian companies are, managers are targeting increase of sales through skills development, exports, branding, value chain cooperation, getting finance and others. Most of the managers are not necessary seeking for product innovation but more for different types of coaching or transfer of knowledge. Their understanding about the role of universities in such activities is not very evident, but they expect more interaction with such an actor. Even more, they expect universities to cover some costs of the managment of these clusters.

Indeed, universities may bring to the companies not only some relief in supporting the costs of cluster formation or development or in initial research and services. They can supply more valued added types of services or knowledge transfer: market intelligence, cluster formation and management, branding and promotion, $\mathrm{R} \& \mathrm{D}$, cluster business plan and strategy, getting finance through several types of projects etc.

To understand what are the preconditions of better cooperation between universities and SMEs organized in clusters we made additional research related to the transfer of knowledge.

\section{Assessment of the exchange of knowledge transfer between SMEs and universities}

The way SMEs are looking to cooperate with universities 
Most of the respondent companies have as activity field professional, scientific and technical activities (23.8\%), processing industry (19\%), agriculture, forestry and fisheries (19\%), construction (14.3\%) and other areas (23.9\%). Of the interviewees, $81 \%$ of them have decisionmaking power in the company, and $61.9 \%$ of companies have between 1 and 10 employees.

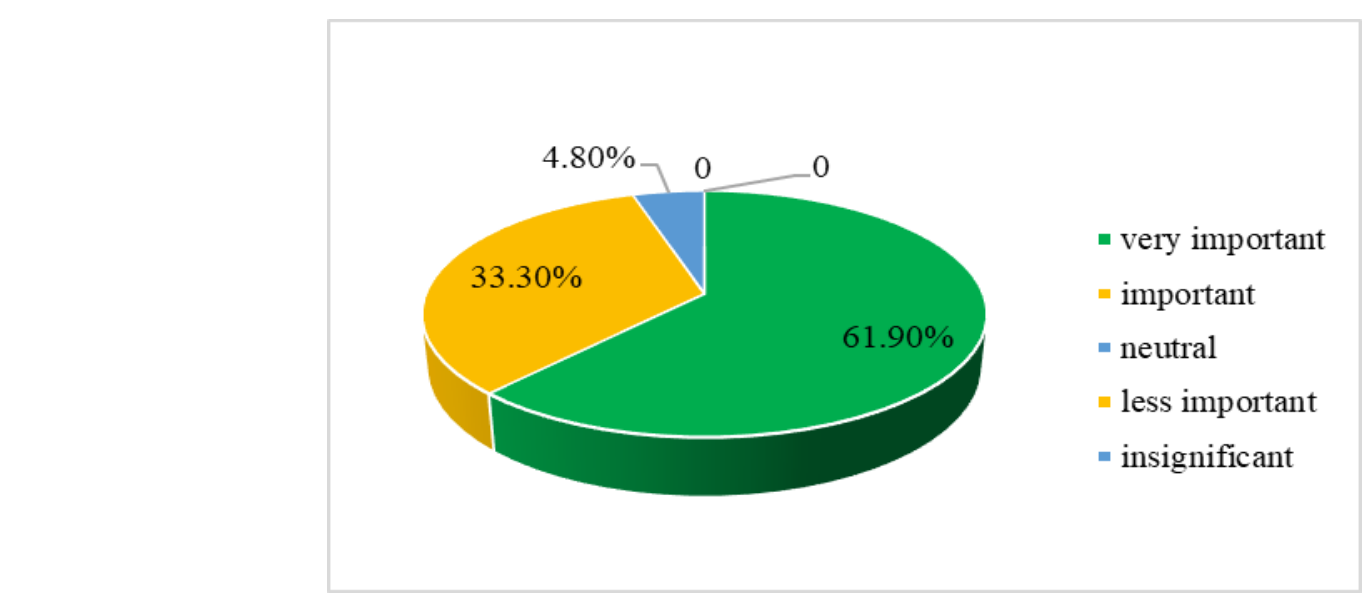

PICBE $\mid 496$

Figure 1. The extent to which the transfer of knowledge from the external environment of the
company is important for the managerial performance

Source: Authors' own research

The research has shown that $52.4 \%$ of SMEs have worked with a university and/or a research institute. On a scale from 1 (insignificant) to 5 (very important) we have found that many companies $(61.9 \%)$ consider the transfer of knowledge form university is a very important process that influences SMEs managerial performance.

In order to identify manager's preferences in the decision-making process regarding the entity to which they must address when they want to get transfer of knowledge, we have considered several categories such as: own R\&D department, universities, technology transfer centers, research institutions, other SMEs, other specialists. A complete picture is presented in Figure 2. As we can see, the companies prefer to collaborate with universities or other SMEs.

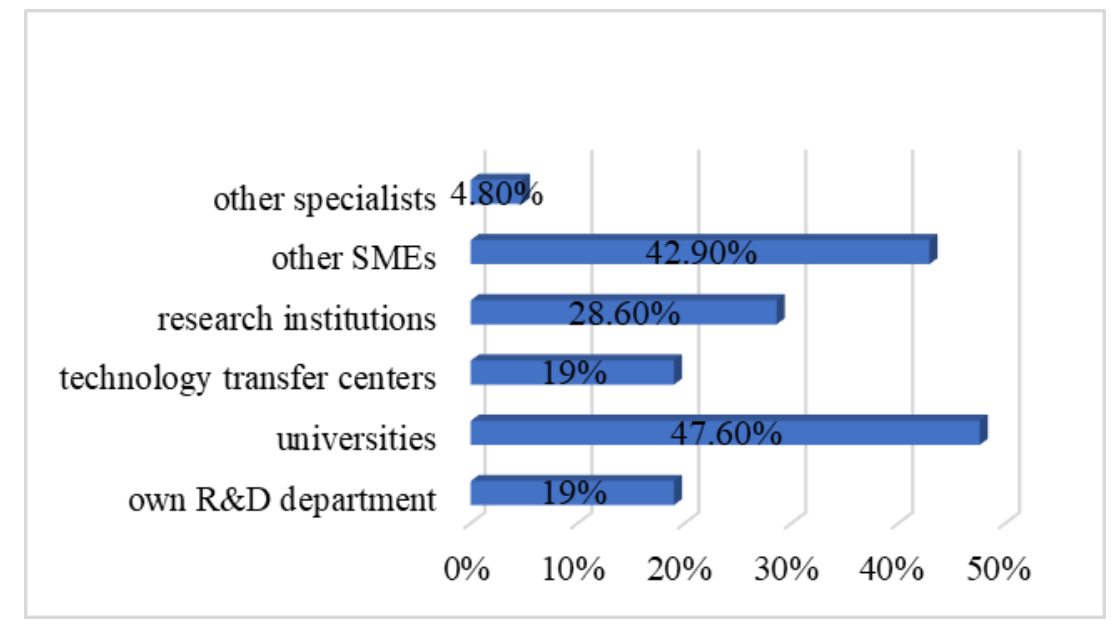

Figure 2. Types of entities which can make knowledge transfer

Source: Authors' own research 
Another research objective has been to identify the main forms of cooperation or common activities which can be done with universities. The results have shown that there are a variety of tools or instruments in which both SMEs and universities can be involved is presented in Figure 3. The SMEs which are cooperating with the universities in the panel, are considering as very important consultancy activities and market studies, and only a few of them are looking to higher very addition cooperation like patents, common research and spin-offs.

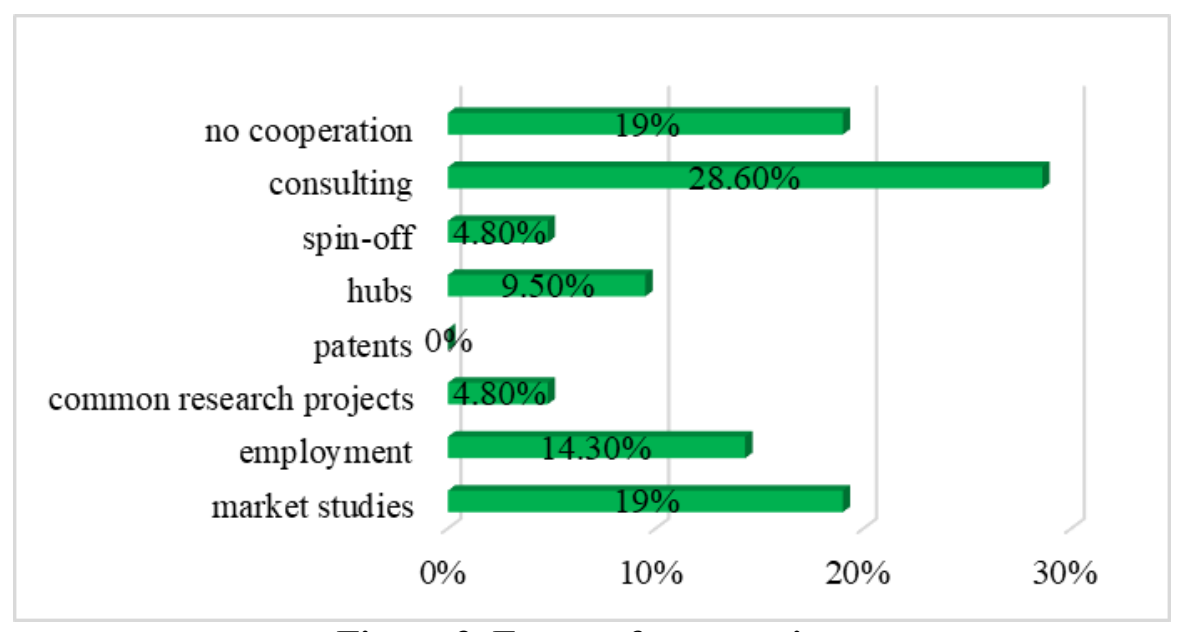

Figure 3. Forms of cooperation

Source: Authors' own research

Despite the wide variety of cooperation forms, there is not enough strategic collaboration at institutional level (only 23.8\%). Still, there is an acute need for the involvement of universities in the activity of companies, a fact confirmed by their expectations regarding the management of the universities. Our study has identified several expectations which could influence and develop, in a positive manner, the SMEs activities. In Figure 4 we can observe the main expectations which can help companies to grow on the market.

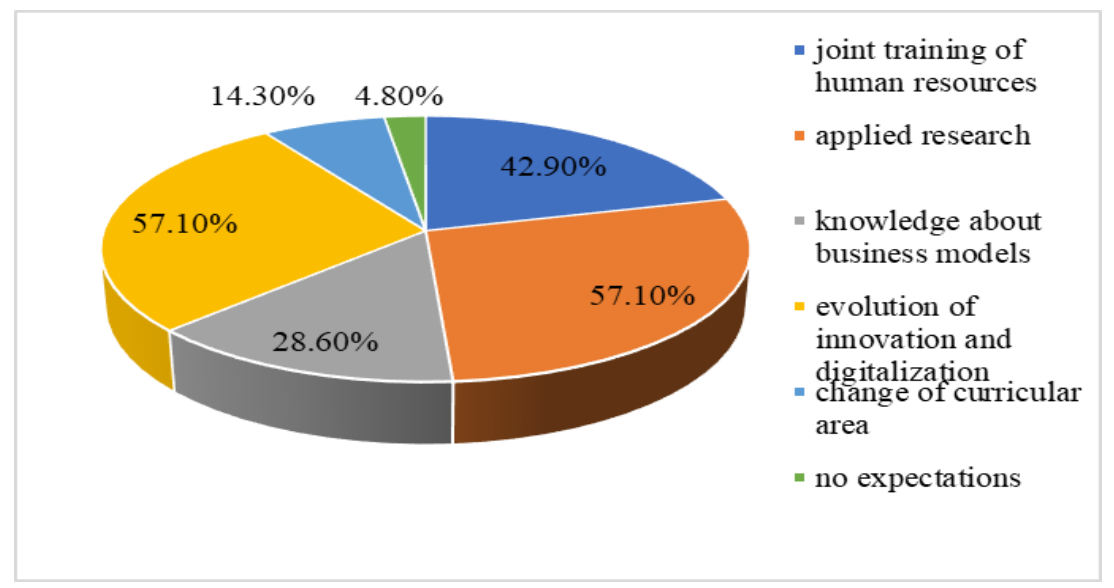

Figure 4. SMEs expectations from management of university

Source: Authors' own research 
After processing the results, we have found that managers consider the applied research and the evolution of innovation and digitalization to be the most important ones. Joint training of human resources is positioned on the second place, and knowledge about business models on the third place.

In order to deepen the research regarding how the cooperation relations between universities and SMEs can be developed, the managers have had the possibility to propose different activities, tools or instruments through which they can attract such kind of cooperation: motivating the university environment by explaining the benefits of implementing projects; direct involvement of the company in the development of projects and partnerships; verifying the availability of the involvement of universities on common topics; development of internship programs; participation in networking events organized in the field of innovation; participation in thematic seminars; sustainability in terms of business strategy.

To represent what kind of qualities should have an external partner which can deliver knowledge transfer, we used a Likert scale. We have analyzed four kind of these qualities like: knowledge of the business, the business model and the market $(71.4 \%$ consider this feature very important); openness to dialogue and understanding the challenges of the company $(76.2 \%$ consider this feature very important); pragmatic attitude of applying theory in practice $(71.4 \%$ consider this feature very important); adaptation of academic knowledge to the new challenges of the entrepreneurial environment ( $76.2 \%$ consider this feature very important).

The way universities are looking to cooperate with companies

The extent with which the transfer of knowledge from the external environment of the university is important for the academic performance varies on a scale from 1 (insignificant) to 5 (very important). After the processing the answers, we have found that many teachers from higher education institutions $(82.35 \%$ ) consider the transfer of knowledge a very important process that influences university performances. We have identified the most important qualities which an external partner of university should have in order to deliver the best knowledge transfer:

- Capacity and interest to implement a scientific research (53\%);

- Openness to dialogue and understanding of scientific challenges ( $82 \%)$;

- Positive attitude towards the importance of the scientific approach in the management of the company $(71 \%)$;

- Adaptation of managerial knowledge at company level to scientific theories (29\%);

- Others - the ability to understand the importance of collaborating with scientific knowledge providers in their business field, in order to know the latest research results in the field of interest and how to translate the research results into the company's activity. 


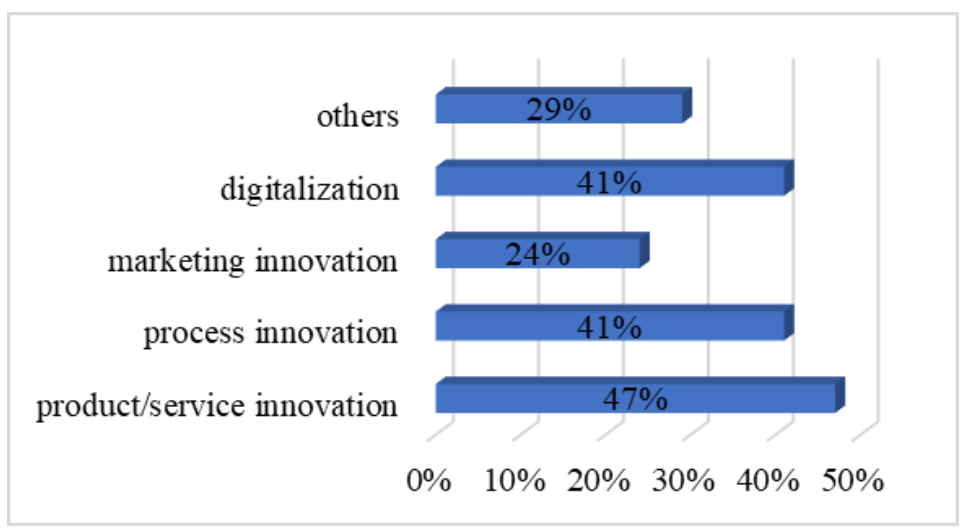

PICBE | 499

Figure 5. Areas of interest

Source: Authors' own research

Our study has identified several areas of interest through which universities could cooperate with business environment, as shown in figure 5. Among them we can mention the exchange of knowledge and ideas, management innovation, support for student training activities (internships, mobility at national and international level), training programs for company managers and employees, and collaborative research projects.

When asked what kind of activities professors are inclined to offer to SMEs the answers were more concentrated on market studies and consultancy. As in the case of SMEs, at the university level high value addition cooperation activities like patents, hubs, spin-offs or common research are not the first priority.

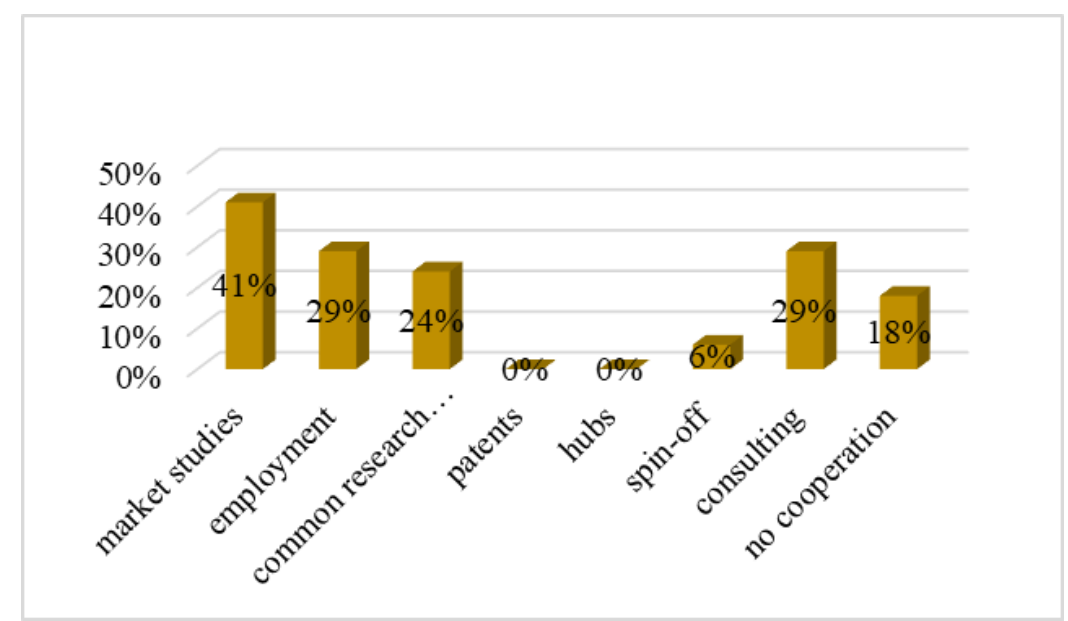

Figure 6. Forms of cooperation with business environment

Source: Authors' own research

Looking at the expectations of the universities when interacting with SMEs, we found more focus on research and curricular change. Indeed, in Figure 7 we can observe professors consider the applied research and the change of curricular area to be the most important ones. 


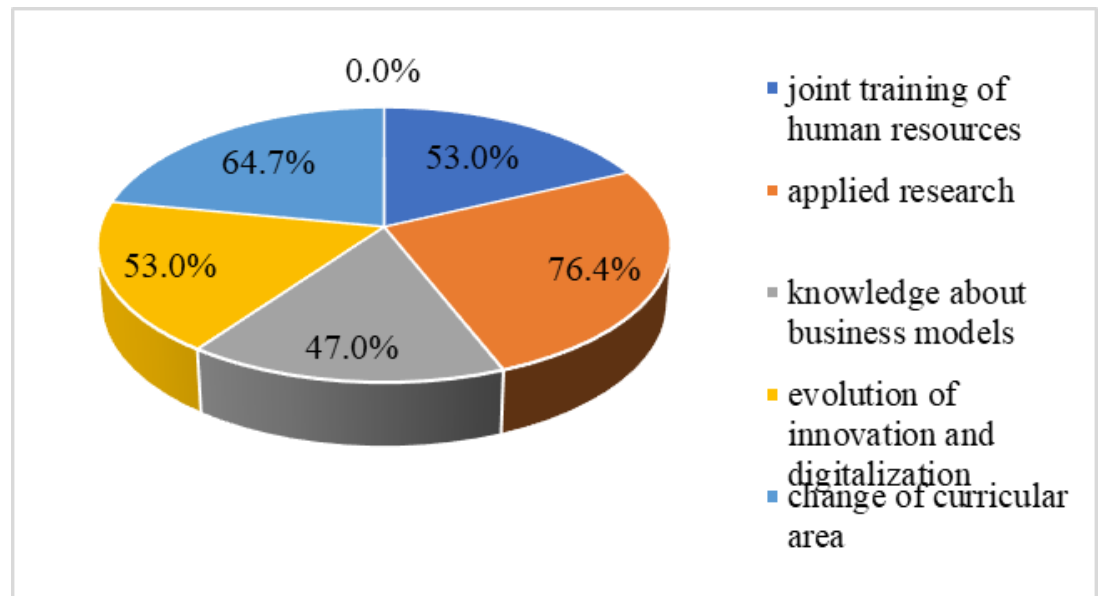

PICBE | 500

Figure 7. University's expectations from SMEs management

Source: Authors' own research

In order to understand the attractiveness of the academic environment for the business environment, we have identified some of the measures or proposals that could lead to a better collaboration between both environments:

- Developing a strategy at the institution level that considers the specialization of each professor;

- Developing a well-built and efficient entrepreneurial university strategy;

- Orientation of the research towards objectives demanded by the business environment;

- Greater university autonomy

- Adapting the curriculum to the demands of the labor market;

- Setting up of clusters and a specialized department of collaboration with the business environment, conceived as an active interface between the teaching staff and the management structures of the economic agents;

- Training of students in the area of competences of interest for the business environment and certification of these competences;

- Collaboration of teacher - specialist in the training process (teachers visit companies and hold interactive seminars and vice versa, those from companies come to colleges and hold workshops);

- Implementation of a new web module for collaboration with the business environment;

- Regular collaboration with SMEs and other entities that can provide important information for understanding the skills needed to develop the university's attractiveness for the business environment;

- The institution should provide clear examples of how the strategy implemented delivers results and opportunities at the institution level and especially for the business environment, in the community (at local, regional level);

- To attract and involve stakeholders with entrepreneurial experience (points of view, knowledge, expertise that does not currently exist internally, from the private, public, NGOs, civil society);

- To provide access to the university facilities of the stakeholders from the community/ region; 
- To encourage dialogue and synergies between the administration, faculties, teachers, students for the exploitation and capitalization of the common knowledge and resources.

\section{Cluster collaboration}

Setting up of clusters as active interface between university and the management structures of a company has been identified as a best practice. In order to understand the degree of cluster collaboration, specific questions were addressed to this issue. At the level of universities most responders declared familiar with the cluster notion (58.8\%) and few $(29.4 \%)$ are very familiar with this concept. At the level of SMEs, most of the responders declared familiar with the cluster notion $(38.1 \%)$ or very familiar $(33 \%)$. Since the responders from both panels are also actively involved in cluster collaboration the results indicate that this form of cooperation is getting more importance in Romania.

\section{Study case - USH Pro Business}

In the last part of our research we want to see patterns of collaborations between SMEs organized in clusters having a university center as a facilitator. USH Pro Business is a dedicated university center for entrepreneurial support activities, designed to assist companies and groups of companies or business associations. It provides cluster focused solutions to sustain competitiveness, innovation and internationalization throughout the business life cycle. Even more, it is financig from its own resosurces cluster formation and development.

The center offers specialized services and assistance through projects and programmes that resulted from the interaction with businesses. USH Pro Business Center brings value to the services existing on the market through better understanding of partner's needs and connecting them with research, innovation and academic infrastructure.

The entrepreneurial center offer tailored services to the Romanian business environment, with a pro-active and innovative attitude through its specialized units for technological transfer "Pro Transfer" and a special entity for internationalization. USH Pro Business brings complete services such as: research and innovation with accent on marketing solutions, professional and vocational training, support services for clusters and companies that need to become competitive on the market and business events. This entity is also part of "Smart eHub", a consortium of organization specialized for digitization services for companies.

One major direction of its activities is dedicated to clusters during 2015-2020. It closely works with clusters specialized in IT\&C (Smart Alliance), energy (CERMAND), food and agriculture (Bio Danubius, Bio Concept Valea Prahovei), engineering (Danube Engineering Hub), furniture (Danube Furniture Cluster), creative industries (Bucharest Creative Cluster) and others. Most of these clusters were facilitated by the center.

The reasons USH Pro Business is active in cluster building and development are the following: the knowledge of the team related to clusters, the ability to create and develop trust with individual companies before the emergence of the cluster, the ability to create alliances with other universities and research institutions.

Beside that USH Pro Business ensures a careful and detailed observation of the changes and trends in the business environment and is a place dedicate to the application of the concept of communities of practice. The center chooses thematic areas to be followed in its services for training Start-ups, internationalization, research and market studies, vocational and professional training, training and development of clusters, innovation management, development of strategies 
for competitiveness and export, consultancy regarding EU and national funds, EU Strategy for Danube Region (EUSDR) and others.

Main instruments of the transfer of knowledge are conferences, seminars and other business events dedicated some major themes like: innovation, new technologies, digitization, market access and entry, getting finance etc. In this way, groups of professionals have been formed acting like communities of practice and transfer of knowledge for their thematic focus.

PICBE | 502

\section{Conclusion}

According to our assessment the process of knowledge transfer between SMEs and universities is in the early stages in the Romanian society. Despite of the fact there is a growing interest of cooperation among managers of SMEs or academics, the scope of this cooperation is connected to more traditional forms of collaboration. Even more, the study shows that expectations form both sides, universities and SMEs are different and their is an acute need of structural dialogue between them in orde to transform each party knowledge and understanding into a share one.

Both managers and academics have to adapt faster through continued dialog and trust building. In this interaction cluster development using university hub as facilitator could be a good option. Clusters are long-term business alliances where both managers and professors are learning from each other. In order to speed up the process of collaboration clusters may adapt models of cooperation envisaged in two modern concepts: communities of practices and smart specialization.

Since regional development in Romania is focused on smart specialization there is a danger to trace policy objectives related to this issue without looking to the ability of transforming tacit knowledge of managers or academics in to a common knowledge, as a prerecuisite of real and efficient smart specialization.

Therefore, the paper shows that even there is a common interest of cooperation this is not yet targeting high value addition cooperation forms like spin-offs, patents, hubs, common research, applied innovation, common commercialization.

According to our study, the process of communities of practices among SMEs, universities and clusters should be embedded in the cluster management and follow the steps as: cluster management targets, knowledge externalization among the group, knowledge internalization among the group, knowledge combination towards innovative products/services, strategic response towards proof of the concept and further innovation levels, cluster management and market validation of innovative solutions.

\section{References}

Acs, Z., Audretsch, D., \& Feldman, M. (1994). R\&D spillovers and recipient firm size. Review of Economics and Statistics, 76(2), 336-340.

Asheim, B., Cooke, Ph., \& Martin, R. (2006). The rise of the cluster concept in regional analysis and policy. In Asheim, B., Cooke, Ph., Martin, R. Clusters and regional development (pp. 1-29).

Audretsch, D., \& Vivarelli, M. (1996). Firms size and R\&D spillovers: Evidence from Italy. Small Business Economics, 8(3), 249-258. 
Baum, J., Calabrese, T., \& Silverman, B. (2000). Don't go it alone: alliance network composition and startups' performance in Canadian biotechnology. Strategic Management Journal, 21(3), 267-294.

Committee of the Regions (2014). Using the Quadruple Helix Approach to Accelerate the Transfer of Research and Innovation Results to Regional Growth. Retrieved from http://cor.europa.eu/en/documentation/studies/Documents/quadruple-helix.pdf.

PICBE $\mid 503$

Dubé, L., Bourhis, A., \& Jacob, R. (2005). The impact of structuring characteristics on the launching of virtual communities of practice. Journal of Organizational Change Management, 18(2), 145-166.

Etzkowitz, H., Webster, A., Gebhardt, C., \& Cantisano, B. R. (2000). The future of the university and the university of the future: evolution of ivory tower to entrepreneurial paradigm. Research Policy, 29 (2), 313-330.

Etzkowitz, H., \& Leydesdorff, L. (2000). The dynamics of innovation: From National Systems and "mode 2" to a Triple Helix of university-industry-government relations. Research Policy, 29 (2), 109-123.

European Commission (2008). Towards world-class clusters in the European Union: Implementing the broad-based innovation strategy. Retrieved from http://eurlex.europa.eu/LexUriServ/LexUriServ.do?uri=COM:2008:0652:REV1:EN:PDF.

European Commission (2018). What is Smart Specialisation? Retrieved from https://s3platform.jrc.ec.europa.eu/en/what-is-smart-specialisation-.

Foray, D. (2015). Smart Specialisation: Opportunities and Challenges for Regional Innovation Policies, Routledge.

Fukugawa, N. (2013). University spillovers into small technology-based firms: Channel, mechanism, and geography. The Journal of Technology Transfer, 38(4), 415-431.

Hassink, R., \& Gong, H. (2019). Six critical questions about smart specialization. European Planning Studies, 27(10), 2049-2065.

Kempton, L., Goddard, J., Edwards, J., Hegyi, F.B., \& Elena-Pérez, S. (2013). Universities and Smart Specialisation. S3 Policy Brief Series No. 03/2013, European Commission Joint Research Centre, Institute for Prospective Technological Studies.

Klofsten, M., \& Jones-Evans, D. (2000). Comparing Academic Entrepreneurship in Europe - The Case of Sweden and Ireland. Small Business Economics, 14(4), 299-309.

Kietzmann, J., Plangger, K., Eaton, B., Heilgenberg, K., Pitt, L., \& Berthon, P. (2013). Mobility at work: A typology of mobile communities of practice and contextual ambidexterity. Journal of Strategic Information Systems, 3(4), 282-297.

Lave, J., \& Wenger, E. (1991). Situated Learning: Legitimate Peripheral Participation. Cambridge: Cambridge University Press.

Lianu, C. (2015). Smart Specialization in the Danube Region, Building Trust through Communities of Practice. ICESBA Papers 2015, www.icesba.eu, Procedia of Economics and Business Administration.

Link, A., \& Rees, J. (1990). Firm size, university-based research, and the returns to R\&D. Small Business Economics, 2(1), 25-31.

Malmberg, A., \& Power, D. (2006). True clusters - A severe case of conceptual headache. In Asheim, B., Cooke, Ph., Martin, R. Clusters and regional development, (pp. 50-68). New York, Routledge.

OECD (2010). Regional development policies in OECD countries. OECD Publishing. 
Philpott, K., Dooley, L., O'reilly, C., \& Lupton, G. (2011). The entrepreneurial university: Examining the underlying academic tensions. Technovation, 31(4), 161-170.

Porter, M. (1998). On competition. Harvard: Harvard Business School Press.

Romijn, H., \& Albaladejo, M. (2002). Determinants of innovation capability in small electronics and software firms. Research Policy, 31(7), 1053-1067.

Rothaermel, F., \& Deeds, D. (2004). Exploration and exploitation alliances in biotechnology: A

PICBE | 504 system of new product development. Strategic Management Journal, 25(3), 201-221.

Secondo. G., Elena-Perez, S., Maaryinaitis, Z., \& Leitner, K.H. (2017). An Intellectual Capital framework to measure universities' third mission activities. Technological Forecasting and Social Change, 123, 229-239.

Shields, P.M. (2003). The community of inquiry: Classical pragmatism and public administration. Administration \& Society, 35(5), 510-538.

Wallace, K. (2007). Educating for autonomy: Identity and intersectional selves. In J. Ryder \& G-R Wegmarshaus (Eds). Education for a Democratic Society (pp. 165-176).

Wenger, E. (1998). Communities of Practice: Learning, Meaning, and Identity. Cambridge: Cambridge University Press.

www.ushprobusiness.ro

www.adf-dfc.ro

www.smartalliance.ro

www.biodanubius.ro

www.clusterdeh.ro 